\title{
日本産ミクラステリアス
}

東 道太郎 水㬄請習所 【㨂圆 12]

Micrasterias from Japan

By Michitaro HIgashu

Imperial Fisheries Institute

\section{Micrasterias AGARDH}

1. Micrasterias alata $\mathrm{W}_{\text {ALLICH }} \beta$. depressa Turner (Fig. 1)

山城巨椋池 (東), 石見蟠龍湖 (東 1916).

2. M. Americana (Ehrenterg) RaLfs

北千島（岡田 1934）.

3. M. apiculata (Ehrenterg) Meneghini

渡島蕇荣沼 (ROY et BISSETT 1886).

3a. var. lacerata FuJISAWA

信濃伊那 (藤澤 1934).

4. M. Crux-Melitensis (EhrenberG) Hassall (Fig. 2)

北千島（岡田 1934), 渡島莓荣沼 (ROT et BISSETT 1886). 信州伊那 (藤澤 1934), 東京品川 (東 1916), 横濱 (Roy et BISSETT 1886), 山城巨椋池 (東).

5. M. denticulata BRÉBISSON

北千島（岡田 1934), 渡島莗茶沼 (Rox et BISSETT 1886), 信 濃八島ヶ池 (牛山 1923), 同伊那 (藤澤 1934).

5 a var. angulosa (HANTZSOH) W. \& G. S. WEST 北干息（岡田 1934).

5b. var. angustisinuata $\mathrm{G}_{\Delta \mathrm{Y}}$

北千島 (岡田 1934).

5c. var. notata NORDSTEDT 


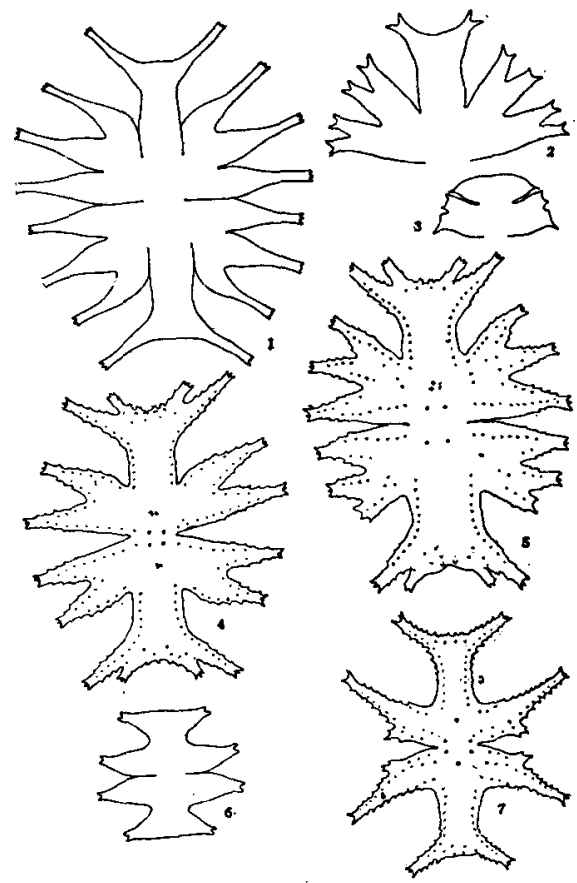

第 1-7 圆 1. M. alata $\beta$ depressa, 2. M. Crux-Melitensis, 3. M. descemdentata, 4. M. Mahabuleshwarensis, 5. M. M. var. Wallichii, 6. M. pinnatifida, 7. M. tropica var. polonica. $\times$ 淤 200

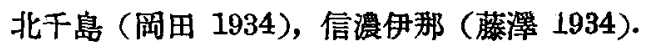

5̃d. var. notata NORDSTEDT f. minor OKADA

北千島パラムシロ（岡田 1934）.

6. M. descemdentata (NÄGELI) ARCHER (-ig. 3)

蕇案沼 (ROY et BrSSETr 1886), 山城巨椋池 (東).

7. M. foliacea BAILEX

武藏嵐山附近（岡田 1936 a), 山城巨椋池（岡田 1936；東）

8. M. Mahabuleshwarensis HoBson (Fig. 4)

山城巨椋池 (東).

8a. var. Wallichit (GRUNOW) W. \& G. S. WEST (Fig. 5)

常陸顶 (東 1916), 山城巨椋池 (東). 

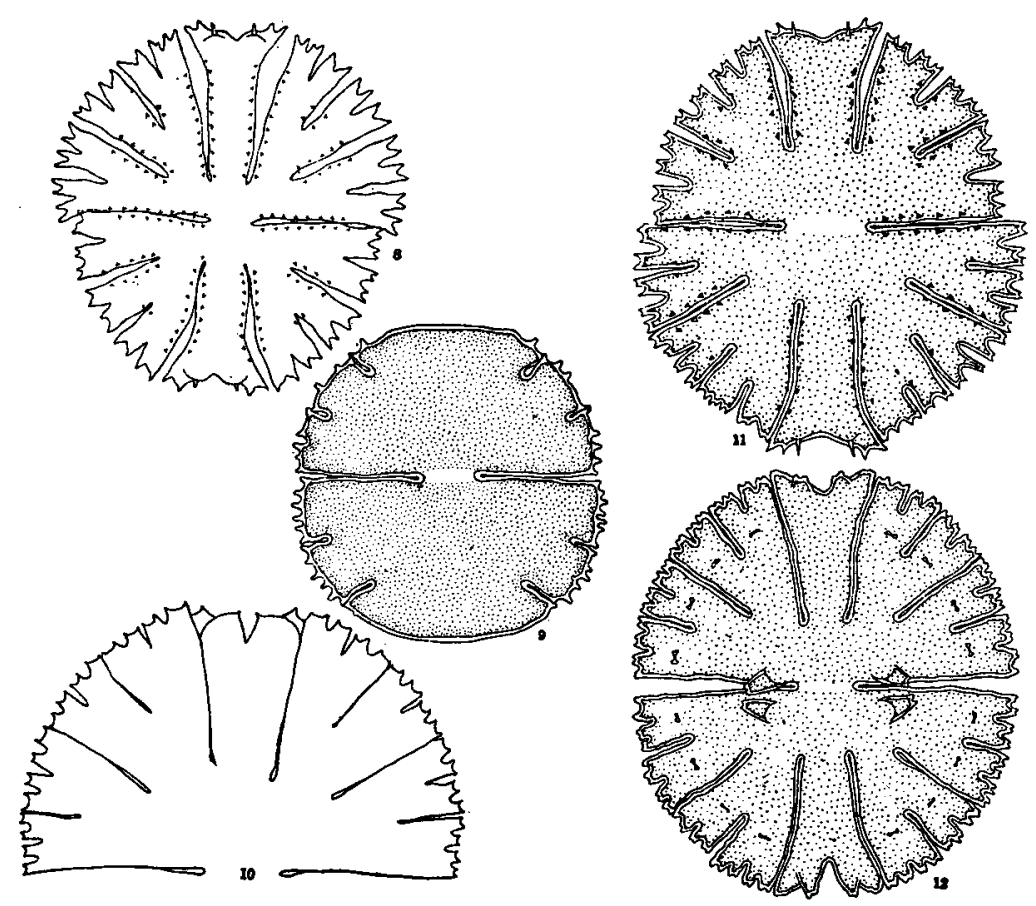

第 8-12 圆 8. M. Sol var. ormata, 9. M. truncata, 10. M. rotata. 11 . M. papillifera, 12. M. Thomasiana. 8 及 11 は $\times$ 約 300 他は $\times$ 約 200

9. M. papiuffera BR\&Bsson (Fig. 11)

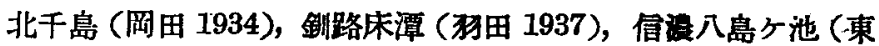
19.c6).

10. Mr. pinnatiflaa (KützING) RALFs (Fig. 6)

北千島（岡田 1934），渡島蓴荣沼 (Ror et BISERT 1886)，常陸 大池（東 1916）, 信濃八島ヶ池 (東 1916), 山域巨棕池（東）, 石見蟠龍湖 (東 1916).

11. M. radians TURNER $\alpha$. typica TURNER

syn. $M$. radians (non TuRner) OKadA 1936 b. p. 431 , pl. 7 , fig. 3. 山城巨椋池（周田 1936)，石見蟠龍湖'(東 1916).

12. $M$. rotata (GRpviLLE) RALFS (Fig. 10) 
北千島（岡田 1934），渡島董荣沼 (Rox et BISSETT 1886)，武 藏八王子 (東).

13. M. Sol (EHRENBerg) KüTZing var. ornata NordsTedT (Fig. 8)

信漫八島ヶ池附近旗河原 (東).

14. ML. Thomasiana ARCHER (Fig. 12)

北千島（岡田 1934），信涱八島ヶ池，鎌ヶ池（東)，同伊那（藤 澤 1934).

15. M. tropica NORDSTEDT var. polonica RACIBORSKI (Fig. 7) 山战巨椋池 (岡田 1934, 東).

16. Mr truncata (CORDA) BrÉBISSON (Fig. 9)

北千島（岡田 1934), 陸奥八甲田山（東), 信惯八島ヶ池，(東

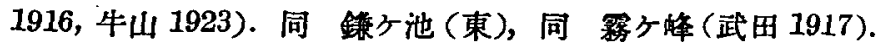

16a. f. granulata RACIBORSKI

信濃八島ヶ池（藤澤，1934）。

17. M. uruniformis W. \& G. S. WEST

信濃霧ケ峰 (岡田 1936).

ミクラステリアス俨は C. A. AGARDH が 1827 年 Flora にて發表せら れたる虽にて，其特微は，

細胞䋺狀に連續するものは 1 種のみにて他の種は單細胞にて孤生す。 多數のものは形態大なり。細胞は强く扁座し廣楕圓形或は亞圓形又は六 角形，中央に深き殓れを有す。各牛絊胞は深き切れ込みによつて更らに 三の裂片に分る。側方の裂片は更らに 1 回乃至數四多少深き切れ込みを 有し，顶端の裂片は全線或は少しく凹むも，猍き切れ込みによつて裂片 に分るる事なし。細胞の一端より見る時は狄き烃圆形にして兩端尖るる， 牛球形に笑出したる隆起を有せす。細胞膜は平滑或は刺又は疫を有す。 裂片の隅角には小なる满を有するものあり。色素體は各斗細胞內に 1 個 つつを有し，中立，板狀にして，牛細胞の內部を允たし總ての突出部內 までる揗がり，其表面には縱走する隆起或は裂片を有す。Pyrenoid は 多數にして色素體內に散在す。接合子は接合管內に形成せられ，球形に して單一又は先端分吱したる强刺を有す。

既知の種は Printz が ENGLer の Die natürlichen Pflanzenfamilien 
第2 版(1927 年) 飞記する處によれば 67 種なり。各國に於ける分布狀態を 見るに，英國には FrITSCH の A Treatise on the British Freshwater Algae 改訂版（1927 年）に上れば 16 種を産し，又北米合臬國には G. M. SMITH の The Fresh-water Algae of the United States (1933 年) によ㣙約 35 種を在すと。之によつて見れば本邦る亦相當多くを库する地方なり。

本邦於ける本屬のbのの最初の發表は Rox and BISSETr にして 1886 年なり。同論文所載の本翼のものは Micrasterias pinnatifida, M. CruxMelitensis, M. descemdentata, M. denticulata, M. rotata, M. apiculata の 6 種去り。

大正 5 年 $(1916$ 年) 岡村博士が 日本藻類名拿の再版出版に際し, 余は Micrasterias truncata, M. papillifera, M. Sol var. ornata, M. MIahabuleshwarersis var. Wallichii, M. alata $\beta$. depressa, M. radians $\alpha$. typica の 6 種を追加記載したり。

大正 7 年 (1918 年) 出版の川村多實二呚授の日本淡水生物學上突には Micrasterias alata 外 8 種の圖を揭載せられたるが，同書によつて新たに 本邦に產するととの知られたるるのは M. foliacea なり。

昭和 9 年 (1.934 年) 藤澤六馬氏は伊那及び八島ケ池座の8のとして本虽 3 種 2 禁種 1 品種を記載せられたるが, 其の中 Micrasterias apiculata var. lacerata は新临種, M. denticulata var. notata, M. Thomasiana, M. truncata f. scrobiculata は新をに本邦に座する事を知られたるものなり。

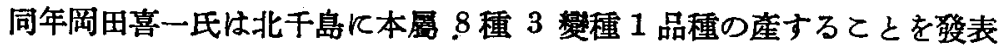
せられたるが，其の中 Micrasterias Americana, M. denticulata var. angulosa, var. ungustisinuata, var. notata f. minor は新をに邦産に加へら れたるものなり。

同 11 年 (1936 年) 同氏は Micrasterias tropica var. polonica, $\boldsymbol{M}$. urniformis の本邦湰するととを報せり。

以上により現に邦座として知られたるすのは 17 種 5 櫟種 2 品種なり。 既知邦库の種類は平地の水田, 湧泉, 小池沼, 瀑原中八池沼等的て探 集せられ, 其の産地は北千島より北海道, 本州北端より近载を經て山陰道

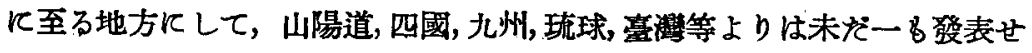
られず。後日此地方にて探集研究行はるれ浭らに邦産を增す事ならん。 本屬のものは産地一地方に局限せられたるものは少なく，多くは世界の 
各地に分布をなしをるるのなるを以て，本邦特㢈のるのは僅かに 1 變軼 1 品種に過守。

次に産地飞關し一二附言せ九に, Rox and BISSETT の研究材料は BIS-

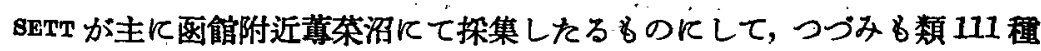

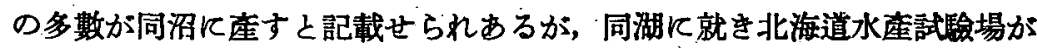
種くの調查をなし發せられたる同場昭和五年七月發行の水座調查報告第

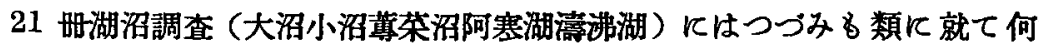

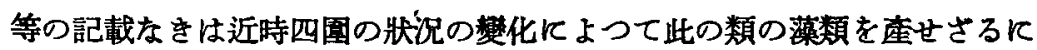
至りしるのか。名信州霧ヶ峰八島ケ池は先年中野治房博士の探集によつて つづみる類の侱座する事を知りえる所なるが，近年池畔飞家屋建設せられ 人の住居するに至り，池水を飲料其他に使用せる爲加濑次減少の㑯向あ り。何とか保存の途を講じ得さるすのにや。又近畿方面に於ける一大座地 なる巨椋池も開笮事業の淮捗と共に其種類を瓝減する事ならん。八甲田山 中にある所謂御田の水中には藍藻, 綠藻の種類多く棲息するもつつみる類

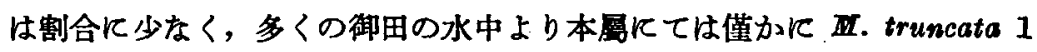
種のみより見られざりしは意外の感あり。

\section{引用文䆛}

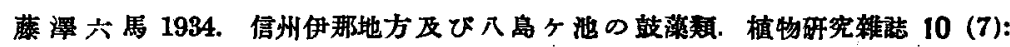
438-445.

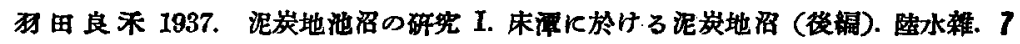
(1): $13-30$.

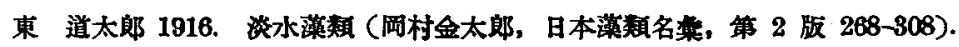

凩田喜一 1934. The Desmid-flora of the Northern Kurile Island. J. Imp. Fish. Inst., $30(3)$ : 123-200.

- 1936. Notes on Japanese Desmids, with Special Reference to the Newly Found Species. I. Bot. Mag., 50 (590): 79-85, Pl. 1.

1936a. - III. ibid. 50 (594): 313-317, Pl. 4.

Roy J. and J. P. Brssetr, 1886. Notes on Japanese Desmids. J. Bot., 25 : 193-196, 237-242.

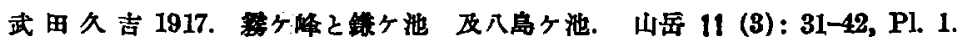

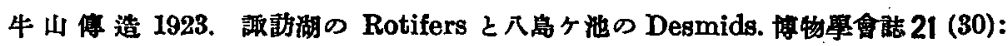
33-35, pl. 2 . 